\title{
ABSTRACTS of
}

Working Papers in

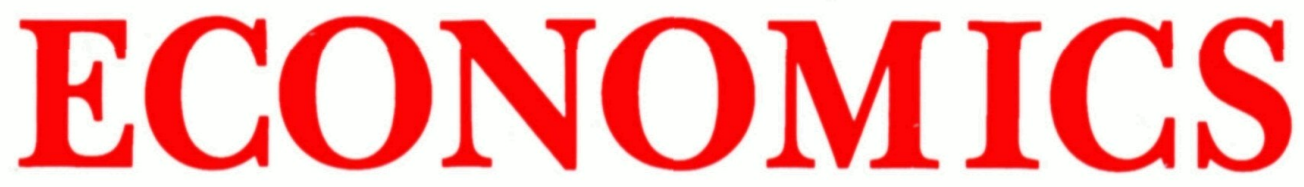

The Official Journal of the AWPE Database

\section{Halbert White, Editor}

\section{CAMBRIDGE}




\title{
ABSTRACTS OF WORKING PAPERS IN ECONOMICS
}

\author{
Editor \\ Halbert White \\ University of California, San Diego \\ Board of Contributing Editors
}

Don Andrews, Yale University

Charles Bates, Johns Hopkins University

Jere R. Behrman, University of Pennsylvania

Anil K. Bera, University of Illinois, Urbana-Champaign

Ben Bernanke, Princeton University

Richard Blundell, University College London

Glen G. Cain, University of Wisconsin-Madison

Chris Cavanagh, Harvard University

Arnold Collery, Columbia University

Meghnad Desai, London School of Economics

Francis X. Diebold, The Federal Reserve System

Michael Dobie, New York University

Jeffrey Alan Dubin, Caltech

Nicholas Economides, Columbia University

Stephen Figlewski, New York University

Gideon Fishelson, Tel Aviv University

Charles S. Gardener, International Monetary Fund

Christian Gourieroux, CEPREMAP

Gene M. Grossman, Princeton University

Sangmoon Hahm, Virginia Polytechnical Institute and S.U.

Michael Haliassos, University of Maryland

A.D. Hall, Australian National University

Jonathan Hamilton, University of Florida

Jay Helms, University of California, Davis

Dale W. Henderson, The Federal Reserve System

James R. Hosek, Rand Corporation

David Humphrey, The Federal Reserve System

Pauline M. Ippolito, Federal Trade Commission

Steve Jones, University of British Columbia

Larry S. Karp, University of California, Berkeley

Nicholas M. Kiefer, Cornell University

Maxwell L. King, Monash University

Jan F. Kiviet, University of Amsterdam

Colin Lawrence, Columbia University

Editorial Assistant

Marion Smith Picard

University of California, San Diego
Richard Layard, London School of Economics Lung-Fei Lee, University of Minnesota

David Levine, University of California at Los Angeles

Ben Lockwood, Birkbeck College

Glenn M. MacDonald, University of Western Ontario

James M. MacKinnon, Queen's University

Robert S. Mariano, University of Pennsylvania

Robect C. Marshall, Duke University

A. Mattei, University of Lausanne

Alain Monfort, I.N.S.E.E.

Whitney Newey, Princeton University

Stephen Nickell, University of Oxford

Michael Porter, Monash University

Marshall B. Reinsdorf, Department of Labor

Stanley Reiter, Northwestern University

Mark Rosenzweig, University of Minnesota

Paul Ruud, University of California, Berkeley

Heike Schmidt, Universität Bonn

Peter Schmidt, Michigan State University

G. William Schwert, University of Rochester

William W. Sharkey, Bell Communications Research, Inc.

Annie Spillane, NBER

Pablo Spiller, Stanford University

Charles Struckmeyer, The Federal Reserve System

Vincent Tarascio, University of North Carolina

Steve Thomas, University of Southampton

Michael A. Toman, Resources for the Future

Hal Varian, University of Michigan

Sheila Verkaeren, Universite Catholique de Louvain

Chris Winship, Economics Research Center/NORC

Glenn A. Woroch, University of Rochester

Adonis Yatchew, University of Toronto

J. Steven Yeo, Centre for Economic Policy Research

Richard Zeckhauser, Harvard University

\section{Managing Editor}

Robin Allen

University of California, San Diego
Editorial Office: Abstracts of Working Papers in Economics. Department of Economics, D-008, University of California San Diego, La Jolla, CA 92903, USA. Tel. (619) 534-3502.

Publishing, Production and Advertising Offices: Cambridge University Press, 40 West 20th Street, New York, NY 10011-4211, USA.

Subscription Office: Cambridge University Press, 110 Midland Avenue, Port Chester, NY 10573-4930, USA (for US/Canada/Mexico); or Cambridge University Press, The Edinburgh Building, Shaftesbury Road Cambridge CB2 2RU, England (for UK/rest of world).

1994 Subscription Information: Abstracts of Working Papers in Economics (ISSN 0951-0079) is published bimonthly. Annual institutional subscription rate: US $\$ 190.00$ in the USA, Canada, and Mexico; UK $£ 132.00$ elsewhere. Individual rates: US $\$ 95.00$ in the USA, Canada, and Mexico; UK $£ 65.00$ elsewhere. Student rate: US $\$ 60.00$ in the USA, Canada, and Mexico only. Prices include postage and insurance. Back volumes available upon request.
Copyright $@ 1994$ Cambridge University Press

All rights reserved. No part of this publication may be reproduced in any form or by any means, electronic, photocopying or otherwise, without permission in writing from the copyright holder.

Photocopying information for users in the USA: The Item-Fee Code for this publication indicates that copying for internal or personal use beyond that permitted by Sec. 107 or 108 of the US Copyright Law is authorized for users duly registered with the Copyright Clearance Center (CCC) Transactional Reporting Service, provided that the appropriate remittance of $\$ .50$ per page is paid directly to: CCC, 222 Rosewood Drive, Danvers, MA 01923. Specific written permission must be obtained for all other copying: Contact your nearest Cambridge University Press office. The Item-Fee Code for this journal is $0951-0079 / 94 \$ 0.00+.50$

Application to mail at second-class rates is pending at New York, NY and additional mailing offices. Postmaster: Send address changes in the USA and Canada to Abstracts of Working Papers in Economics, Subscription Department, Cambridge University Press, 110 Midland Avenue, Port Chester, NY 10573. 